\title{
KUALITAS PENGAJAR DAN HUBUNGANNYA DENGAN KEPUASAN MAHASISWA DI SEKOLAH TINGGI PARIWISATA $X$
}

\author{
Kukuh Galih Subekti \\ Hotel Manajemen, Fakultas Ekonomi dan Bisnis, Universitas Bina Nusantara \\ Jln. K.H. Syahdan No. 9, Palmerah, Jakarta Barat 11480 \\ k_galihsubekti@yahoo.com
}

\begin{abstract}
Educational institution as a provider of skilled manpower in the tourism industry is the focus of the research field of tourism. Education was instrumental in creating quality human resources. Education in the teaching process can be interpreted as a process of creating a quality resource. Today many emerging institutions or educational institutions have a similar goal, promoting competition in terms of absorption of students with the advanced system of teaching, facilities and quality teachers. Students as customers of the educational institution require the services here in the form of reciprocal teaching with payments to educational institutions. Students can stay in one educational institution if the service of educational institutions provides benefits to student functions.
\end{abstract}

Keywords: teacher quality, student satisfaction, tourism high school

\begin{abstract}
ABSTRAK
Lembaga pendidikan sebagai penyedia tenaga kerja terampil di industri pariwisata merupakan fokus dari penelitian bidang kepariwisataan. Pendidikan sangat berperan dalam menciptakan sumber daya manusia yang berkualitas. Pendidikan dalam proses pengajaran dapat diartikan sebagai suatu proses penciptaan sumber daya yang berkualitas. Dewasa ini banyak bermunculan institusi atau lembaga pendidikan yang satu sama lain mempunyai tujuan satu sama sehingga terjadi persaingan dalam segi penyerapan mahasiswa dengan mengedepankan sistem pengajaran, fasilitas maupun kualitas pengajar. Mahasiswa sebagai pelanggan dari dari lembaga pendidikan membutuhkan pelayanan yang di sini berupa pengajaran dengan timbal balik pembayaran kepada lembaga pendidikan. Mahasiswa dapat bertahan di satu lembaga pendidikan apabila pelayanan dari lembaga pendidikan memberikan fungsi manfaat kepada mahasiswa.
\end{abstract}

Kata kunci: kualitas pengajar, kepuasan mahasiswa, sekolah tinggi pariwisata 


\section{PENDAHULUAN}

Lembaga pendidikan sekarang ini, dituntut memberikan pengetahuan dan pelatihan kepada mahasiswa. Dengan mengarah kepada kebutuhan industri, mata kuliah yang diberikan kepada mahasiswa disusun sesuai Standar Kompetensi Nasional Indonesia (SKNI) yang ditetapkan oleh pemerintah. Penelitian perlu terus dikembangkan di lembaga pendidikan dari penelitian murni atau dasar untuk menghasilkan ilmu-ilmu kepariwisataan sampai cabang dan ranting ilmunya. Di samping itu, penelitian terapan juga perlu dikembangkan guna menyempurnakan penyelenggaraan pendidikan. Penelitian yang dapat dilakukan antara lain penyempurnaan kurikulum mata kuliah kepariwisataan, efektifitas pengajaran, dan relevansi program pendidikan dengan kebutuhan industri pariwisata.

Lembaga pendidikan dan mahasiswa tidak dapat dipisahkan satu sama lain karena keduanya saling membutuhkan. Di antaranya mahasiswa membutuhkan ilmu pengetahuan dan sertifikasi, sedangkan lembaga pendidikan membutuhkan mahasiswa sebagai sumber dana untuk kelangsungan penyelenggaraan kegiatan pendidikan itu sendiri. Mahasiswa di sini dapat dikatakan sebagai pelanggan dari lembaga pendidikan sehingga penting untuk mengetahui tingkat kepuasan setelah mengikuti proses pengajaran.

Kualitas Pengajaran. Kualitas adalah sebuah kata kunci yang bagi penyedia jasa layanan jasa sangat penting. Aplikasi kualitas merupakan bagian dari pengajaran yang utama dari sebuah lembaga pendidikan dalam rangka meraih keunggulan yang berkesinambungan, baik sebagai lembaga pendidikan terdepan maupun sebagai strategi untuk terus berkembang. Keunggulan dari produk jasa berupa pengajaran bergantung pada kualitas yang diperlihatkan oleh jasa tersebut, apakah sudah memenuhi harapan dan keinginan pelanggan yang di sini adalah mahasiswa.

Menurut Rey dan Wieland (1985), "consistent delivery of services and product based on standards established by individual properties or chains" dan menurut Parasuraman, Zeithaml dan Berry (1990), "Quality is exceeding what customer expect from the service". Pengertian dari kedua pernyataan tersebut adalah pelayanan dan produk dikatakan berkualitas apabila telah memenuhi standar yang ditetapkan sekaligus memenuhi harapan pelanggan secara tepat.

Pengajaran merupakan satu bentuk pelayanan lembaga pendidikan terhadap pelanggannya, yaitu mahasiswa. Salah satu cara lembaga pendidikan untuk dapat unggul dalam bersaing dengan kualitas yang lebih tinggi dari pesaingnya secara konsisten. Menurut Ali (1983), "terdapat prinsip umum yang harus dijadikan pegangan dosen atau pengajar dalam proses belajar mengajar, yaitu mengajar harus berdasar pengalaman yang sudah dimiliki siswa; pengetahuan dan keterampilan yang diajarkan harus bersifat praktis; mengajar harus memperhatikan perbedaan individual uang berbeda seperti bakat dan intelegensi; kesiapan (readiness) dalam belajar sangat penting dijadikan landasan dalam mengajar; tujuan pengajaran harus diketahui mahasiswa; dan mengajar harus mengikuti prinsip psikologi tentang belajar. Pemenuhan prinsip prinsip tadi merupakan kunci terjaganya kualitas pengajaran sebagai suatu bentuk pelayanan lembaga pendidikan kepada mahasiswa.

Menurut Kasper, Van Helsdingen, dan Vries (1999), "Everyone in the organization is responsible for delivering quality, customer also contribute to the levelof service quality". Menunjukkan bahwa tidak hanya dosen sebagai pengajar saja yang mempunyai peran dalam penyampaian pelayanan dalam bentuk pengajaran yang berkualitas, tetapi mahasiswa sebagai konsumen juga turut memiliki peran didalamnya. Menurut Tjiptono (2002), "kualitas pelayanan adalah tingkat keunggulan yang diharapkan dan pengendalian atas tingkat keunggulan tersebut untuk memenuhi keinginan pelanggan.” Lebih lanjut Tjiptono mengutip tulisan Parasuraman bahwa ada 2 faktor utama yang mempengaruhi kualitas pelayanan, yaitu expected service dan perceived service. 
Apabila pelayanan yang diterima sesuai dengan yang diharapkan, maka kualitas pelayanan dipersepsikan baik dan memuaskan. Jika pelayanan yang diterima melampaui harapan, maka pelayanan dipersepsikan sebagai kualitas yang ideal. Sebaliknya, jika pelayanan yang diterima lebih rendah dengan yang diharapkan oleh mahasiswa, maka kualitas pelayanan dipersepsikan buruk. Di sini pelayanan dapat diartikan sebagai pengajaran yang baik atau tidaknya kualitas pengajaran bergantung kepada kemampuan pengajar dalam memenuhi pelanggannya, yaitu mahasiswa secara konsisten.

Kepuasan Mahasiswa. Mahasiswa sebagai pelanggan atau pengguna jasa pada satu lembaga pendidikan memang harus dipuaskan sebab tingkat kepuasan ini mempengaruhi konsistensi mahasiswa pada suatu lembaga pendidikan. Bukan tidak mungkin apabila tidak tercapai kepuasan dari mahasiswa akan mengakibatkan pindahnya mahasiswa tersebut ke lembaga pendidikan yang lain. Pimpinan atau pihak manajemen dari lembaga pendidikan harus berusaha melakukan pengukuran tingkat kepuasan mahasiswa agar segera dapat diketahui dan minimalisasi faktor yang membuat mahasiswa tidak puas serta memperkuat faktor yang telah memuaskan mahasiswa. Mengukur tingkat kepuasan mahasiswa bukanlah merupakan proses yang mudah karena data yang diperoleh relatif bersifat subjectif, sesuai dengan jawaban responden menurut pengalaman mereka.

Menurut Kotler (1997), "satisfaction is a person feeling of pleasure or disappointment resulting from comparing a product perceived performance is relation to his or her expectations". Dapat diartikan bahwa kepuasan adalah perasaan seseorang akan kesenangan atau kepuasan hatinya ataupun rasa kecewa karena hasil akhir dari perbandingan realitaproduk dengan relasinya terhadap harapan- harapan yang diberikannya pada produk tersebut. Sebagai pelanggan yang terus menerus mempergunakan jasa lembaga pendidikan dalam kurun waktu tertentu, mahasiswa merupakan pelanggan yang harus diperhatikan benar kebutuhannya akan pengetahuan, sehingga terpuaskan dengan tepat dan memperoleh manfaat dari apa yang didapatkan selama berada dalam lembaga pendidikan.

Hubungan Kepuasan Mahasiswa dan Kualitas Pengajaran. Hal yang penting dari keberhasilan kepuasan mahasiswa adalah bagaimana cara mahasiswa dapat menjadi puas atau tidak puas dengan pengajaran mata kuliah. Kepuasan mahasiswa bergantung pada keseimbangan antara harapan dan pengalaman mahasiswa selama pada proses pengajaranyang diberikan oleh lembaga pendidikan. Ketika suatu lembaga pendidikan mampu mengakomodasi pemenuhan ini, maka mahasiswa akan merasa puas. Pada lain pihak, mahasiswa akan senantiasa menaikkan harapan-harapannya, maka sangat penting apabila lembaga pendidikan dapat terus menerus meningkatkan kualitas.

\section{Mengukur Kepuasan}

Untuk mengukur kepuasan dalam bidang jasa dapat digunakan suatu metode alat ukur yang dikemukakan oleh J. Supranto (2001), disebut dengan Importance Performance Analysis yaitu suatu alat ukur untuk menganalisa kualitas pelayanan yang menggunakan kuisioner sebagai alat pengumpulan data. Selanjutnya, data yang terkumpul diukur dengan fokus pada tingkat kesenjangan atau gap antara tingkat kepentingan konsumen atas kualitas pelayanan yang diharapkan dengan tingkat kepuasan konsumen atas kualitas yang diharapkan dengan tingkat kepuasan atas kualitas pelayananyang diharapkan dengan tingkat kepuasan konsumen atas kualitas pelayanan yang diterima.

Metode ini dijalankan dengan melakukan pengukuran terhadap lima dimensi kualitas pelayanan, yaitu (1) Tangible, berwujud secara fisik, sesuatu yang terlihat secara nyata dengan contoh penampilan pengajar, fasilitas ;pengajar, ruang kelas, dan fasilitas fisik lainnya seperti peralatan dan perlengkapan yang menunjang pelaksanaan pengajaran; (2) Reliability, keandalan, yakni kemampuan lembaga pendidikan untuk memberikan pelayanan sesuai dengan yang dijanjikan secara tepat dan terpercaya kepada mahasiswa; (3) Responsiveness, ketanggapan, yakni kesadaran atau keinginan untuk cepat bertindak membantu dan memberikan pelayanan dengan tepat waktu; (4) Assurance, jaminan, 
pengetahuan, dan kesopanan serta kepercayaan diri para pengajar dengan cirri kompetensi untuk memberikan pengajaran, sopan serta menghargai mahasiswa; (5) Empathy, memberi perhatian kepada setiap mahasiswa secara khusus dengan ciri kemauan untuk melakukan pendekatan, memberikan perlindungan dan usaha untuk mengerti keinginan,kebutuhan, dan perasaan mahasiswa.

\section{Visi dan Misi Lembaga}

What is a Vision? Dalam dunia pendidikan visi dapat diartikan sebagai suatu bentuk pernyataan, seperti apa kualitas suatu lembaga pendidikan pada suatu waktu tertentu di waktu yang akan datang. Pada dasarnya, visi adalah suatu harapan, impian atau cita cita yang ingin dicapai suatu saat. Dalam kepariwisataan, Singapura pernah merumuskan visinya sebagai "A development Country Like Switzerland In 1999”. Memasuki abad ke-21, Singapura memperbaharui visinya menjadi : “A Tropical city of excellence and intelligent island for the next century" dan kemudian berubah lagi menjadi "Miami In the Far east".

Visi itu sebenarnya menjawab pertanyaan "where we want to be in the new future" dan "how will we LOOK and WHEN?". Jadi, visi itu tidak lain adalah "An Inspirational Statement of a desired Future State". Walau visi suatu impian, visi itu harus realistis, harus jelas apa yang akan dicapai dan kapan dicapainya, dalam jangka waktu berapa lama dan yang penting harus ada ukuran dan cara cara pencapaiannya.

Apa manfaatnya suatu lembaga pendidikan memiliki visi? Apakah memiliki visi itu tidak berlebihan? Untuk jangka panjang, visi sangatlah diperlukan. Alasannya adalah (1) Dengan memiliki visi, setiap individu dalam lembaga mengetahui targetyang akan dicapai dalam suatu periode tertentu; (2) Seluruh karyawan mengetahui urutan urutan pekerjaan yang akan dilakukan terlebih dahulu; (3) Dengan memiliki visi, manajemen didorong untuk mengalokasikan semua sumber daya yang dimiliki lembaga, dan semua kegiatan harus terencana dengan baik; (4) Visi dapat memberikan motivasi, identifikasi dan kebanggaan bagi karyawan serta pengajar; (5) Visi bila diikuti dengan baik dapat memberi arah untuk bertindak bagi manajemen; (6) Visi dapat memberikan gambaran yang jelas apa yang akan dicapai dalam suatu periode di masa yang akan datang; (7) Visi mendorong manajemen agar selalu berpandangan jauh ke masa depan yang lebih cerah bagi lembaga.

Seperti contoh visi yang akan penulis ambil dari Sekolah Tinggi Pariwisata X, yaitu menjadikan Sekolah tersebut sebagai centre of excellence, pusat studi kepariwisataan nasional. Tidak mudah merumuskan visi suatu lembaga pendidikan, harus didahului dengan diskusi diskusi dan perlu mengundang pakar untuk memberi masukan sesuai dengan perkembangan industri pariwisata. Selain juga harus melakukan SWOT Analysis.

Misi lembaga pendidikan sebenarnya tidak lain adalah mencerdaskan anak didik atau secara popular atau ideal dikatakan "mencerdaskan bangsa". Bagi lembaga pendidikan kepariwisataan, misi dapat kita katakan sebagai suatu usaha terencana tentang pendidikan dan pelatihan dalam bidang pariwisata. Tujuannya tidak lain adalah memiliki SDM pariwisata yang mampu mengemban tugas profesinya sesuai dengan kebutuhan industri. 


\section{SIMPULAN}

Mahasiswa sebagai pelanggan atau pengguna jasa pada satu lembaga pendidikan memang harus dipuaskan sebab tingkat kepuasan ini mempengaruhi konsistensi mahasiswa pada suatu lembaga pendidikan. Kepuasan mahasiswa juga bergantung pada keseimbangan antara harapan dan pengalaman mahasiswa selama pada proses pengajaran yang diberikan oleh lembaga pendidikan. Harapan ini akan senantiasa berubah sehingga sangat penting apabila lembaga pendidikan dapat terus menerus meningkatkan kualitas. Mengukur tingkat kepuasan mahasiswa bukanlah merupakan proses yang mudah karena data yang diperoleh relatif bersifat subjectif, sesuai dengan jawaban responden menurut pengalaman mereka. Importance Performance Analysis dapat digunakan untuk mengukur kepuasan dalam bidang jasa dengan mengukur lima dimensi pelayanan, yaitu Tangible, Reliability, Responsiveness, Assurance, dan Empathy. Selain itu lembaga pendidikan sebaiknya memiliki visi karena dengan memiliki visi, setiap individu dalam lembaga mengetahui target yang akan dicapai dalam suatu periode tertentu; dan akibatnya bisi dapat memberikan motivasi, identifikasi dan kebanggaan bagi karyawan serta pengajar. Lalu visi dapat memberikan gambaran yang jelas apa yang akan dicapai dalam suatu periode di masa yang akan datang dan visi mendorong manajemen agar selalu berpandangan jauh ke masa depan yang lebih cerah bagi lembaga.

\section{DAFTAR PUSTAKA}

Ali, M. (1983). Guru dalam proses belajar mengajar, Bandung: Asyraf.

Kasper, H., Van Helsdingen, P., Vries, W. Jr. (1999). Services Marketing Management. An International Perspective. John Wiley \& Sons, Chichester.

Kotler, P. (1997) “Managing service businesses and product support services.”. Prentice Hall.

Parasuraman, A., Zeithaml, V.A. dan Berry, L.L. (1988) SERVQUAL: a multiple-item scale for measuring consumer perceptions of service quality. Journal of Retailing 64 1, pp. 12-40.

Rey, A.M. dan Wieland, F. (1985) Hospitality Management Library: Food \& Beverage Service. , Educational Institute of the American Hotel \& Motel Association, East Lansing, Michigan.

Supranto, J. (2001) Pengukuran Tingkat Kepuasan Pelanggan Untuk Meningkatkan Pangsa Pasar. PT. Rineta Cipta. Jakarta.

Tjiptono, F. (2002) Strategi Pemasaran. Edisi ke 2. Yogyakarta: Andi Offset. 